Journal of Economics and Behavioral Studies

Vol. 3, No. 5, pp. 317-325, Nov 2011 (ISSN: 2220-6140)

\title{
Singapore's Venture into the Gulf: Undiscovered Treasure or Empty Pot?
}

\author{
*Caroline YEOH, Wilfred HOW, Joses Wong \\ Singapore Management University \\ *carolineyeoh@smu.edu.sg
}

\begin{abstract}
Singapore: a country synonymous with business efficiency, strict laws and a reputation that belies its miniscule size. Its state-enterprise network and attempts at grafting "Singapore-styled" investment enclaves onto foreign locales often receive attention from the international community. These stateengineered projects are premised on the exportability of Singapore's state credibility, systemic and operational efficiencies as well as the technological competencies of Singapore companies, to locations where these attributes are less distinct. This paper, as part of our series on this topic, revisits the city-state's determined efforts to encapsulate economic space for Singapore-based firms, enabling them to expand beyond the region. This paper however, focuses specifically on the gambits of Singapore's government-linked companies (GLCs) in the Gulf region (GCC countries). Our research shows with purely commercial purposes as the priority, political objectives (and the attendant advantages and complications) tend to take a back seat; that, following from this, the ostensible strategic advantages present in Singapore-styled management and methodology remain uncertain; and that socio-political intricacies in new environments often stymie efforts to import competencies and business practices wholesale.
\end{abstract}

Key Words: Internationalization, Singapore's Government-Linked Companies, GCC Countries

\section{Introduction}

From its independence as a nation-state, Singapore has always recognized the need to be plugged into the global economy. Its lack of natural resources made it imperative for the city-state to develop the ability to leverage on global resources for economic growth and the government's aggressive approach to woo foreign multinational companies (MNCs) to fuel the city-state's economic development is well documented (Huff, 1995; Blomqvist, 2001). However, rising business costs in the 1980s and added competition from neighboring cities like Hong Kong and Shanghai catalyzed the process to shift away from labor-intensive activities to higher value-added ones. Singapore's economic planners sought to expand the island's investment horizons through an overseas direct investment program launched in 1988 but most of these investments proved unsuccessful, resulting in enormous losses by the early 1990s. The 1993 Regionalization Forum (Singapore Economic Development Board (SEDB), 1993) re-positioned Singapore's internationalization stratagem, and the policy documents, Singapore Unlimited and Regionalization 2000 (SEDB 1995a; 1995b) encapsulates the paradigm shift from 'outer globalization' to 'inner globalization'. A new phase in the internationalization strategy was a re-focus on Asia, rationalized by the liberalization of foreign investment controls occurring at the time in countries like Indonesia, China and Vietnam, and the high growth rates these economies were achieving (Regnier, 1993; Mahizhnan, 1994; Perry, 1995; Tan, 1995; Okposin, 1999).

The regionalization program was launched in the early 1990s, involving the establishment of overseas industrial townships to create 'Singapore-styled' business environments for local and Singapore-based multinational enterprises (MNEs) to expand regionally and redistribute their resource-dependent operations to these sites. The Singapore government's role has been acknowledged, and government-linked companies (GLCs) were the prime investors in the infrastructure and real estate development sectors (Zutshi \& Gibbons, 1998). The Singapore government also initiated a series of platforms for strategic discussions and collaboration to market Singapore's overseas industrial parks, and introduced a range of incentives and regulatory innovations designed to assist private companies and individuals in moving overseas (Singapore Ministry of Finance, 1993). A conclusion on the effectiveness of this stratagem has yet to be reached, but it is evident that the initial projects have achieved at least some of their aims (Yeoh \& How, 2006; How \& Yeoh, 
2007); and certainly, the Singapore government, practical-minded as it is, must already be looking further afield for ways to create economic space for the city-state and its corporate components. And indeed, Singapore's aims have expanded, arguably, from regionalization to internationalization; and the latest area of focus for the city-state is the rich, vibrant and expanding region of the Gulf Co-operation Council (GCC).

As such, this preliminary paper presents an overview of Singapore's gambits in the region, and case studies of selected internationalizing companies, paying particular attention to the impact of local socio-political influences, and whether the transfer of core competencies carrying the 'Singapore brand name' has been successful. To provide context to this paper, the theoretical considerations are set out in the next section, followed by a sketch of the political and economic landscape of the GCC economies. Thereafter, we present case studies of three Singapore GLCs that have ventured into these two GCC economies, discuss the various issues and challenges faced by these companies with reference to more specific case studies. The final section considers the implications of these experiences for Singapore's internationalization stratagem, and the citystate's strategic intent to harness synergistic complementarities to reconfigure the Singapore economy for the international marketplace; and discusses some of the pertinent lessons thereof for Singapore, and, indeed, for all governments with an eye towards internationalization.

\section{Literature Review}

Dunning's (1988) eclectic paradigm sought to provide the analytical basis for explaining the patterns and activities of firms beyond their national boundaries. The OLI paradigm seeks to explain the ability and willingness of firms to serve markets, and to look into the reasons for their choice of exploiting this advantage through foreign production rather than domestic production, exports or portfolio resource flows through the interaction of Ownership-specific (O) advantages, Location-specific (L) advantages, and Internalizationincentive (I) advantages. Specifically, the OLI paradigm postulates that firms excogitate the 0 -advantages through the exploitation of firm-specific resources, and the simultaneous procurement of I-advantages through the diminution of transaction costs i.e. foreign investment will only occur if it is advantageous to combine spatially transferable intermediate products in the home country, with at least some immobile factor endowments or other intermediate products in another country.

The framework goes on to assert that the importance of each advantage of the OLI triumvirate, and the relationships between them, varies across firms, industries and countries, and are context-specific; based on factors, including the firm's country of origin, and the country it seeks to invest in. Subsequent iterations drew attention to (Location)-advantages (Porter, 1994, Dunning, 1998; Jovanovic, 2003), including the role of infrastructure in the attraction of new investments (Peck, 1996); the presence of immobile clusters of complementary value-added activities (Markusen, 1996), and the agglomeration economies of spatial proximity (Porter, 1996, 1998). As well, as firm's core competencies become increasingly knowledgeintensive, the location in which firms locate their production, organization and use of assets emerges as a critical competitive advantage (Dunning, 2001). MNEs continue to seek locations (economic and institutional facilities) that are best utilizing their core competencies.

More recent literature has widened the ambit on the role of governments in advancing the competitiveness of a country (or region within a country), as created assets supersede natural factor endowments as the key determinants of location (Dunning and Narula, 1996, 2000; Stopford, 1999; Lundan, 2003). Inter alia, governments need to ensure that availability, quality and cost effectiveness of general purpose inputs match up to the standards of their global competitors, create and sustain an institutional framework and ethos that facilitates a continuous upgrading of the resources and capabilities within its jurisdiction and facilitate, rather than impede micro-regional clusters development and upgrading (Porter, 2000). Singapore's foray into the GCC countries represent collaborative efforts by the Singapore and respective local governments to create location-bound advantages within more uncertain environments, through a propitious combination of costeffective factors of production, efficient infrastructure and management expertise, i.e. supplementing natural location-specific advantages with engineered ones, crafted to complement the economic diversification efforts in the host locations. The strong presence of Singapore's GLCs amongst the internationalizing firms, and the plethora of incentives made available to Singapore firms venturing into the GCC, maintain the 
relevance of discussion of political aims, inter alia, the business-government nexus in alliance capitalism (Dunning, 1995, 1997).

In the following section, we sketch the political and economic landscape of the GCC economies entered into by the companies covered in this paper. Thereafter, we present case studies of Singapore government-linked companies that have ventured into these two regions, discuss the various issues and challenges faced by these companies with reference to more specific case studies, and finally conclude with our preliminary conclusions on the state of Singapore internationalization into the GCC region.

Cities in The Desert: The current prominence of the GCC economies in terms of business opportunities in general, and property developments in particular, has been the direct result of a pace of construction nothing short of breakneck, and a scale of investment only describable as overwhelmingly immense. Driven, popular knowledge claims, primarily by surges in oil prices and consumption in the late 1990s to early 2000s, this increased focus on the development of infrastructure, tourism, and industrial and educational foundations in the less troubled parts of the Middle East was born from the realization that oil could not continue to be the main and only relevant revenue stream of the region (Abouchakra, et al, 2008). Thus, there existed a need to strongly promote the region, to overcome a measure of international ignorance owing to the tendency of the popular media to focus on the unstable elements of the Middle East, and exacerbated by the terrorism phenomenon. As such, there has been the plethora of mega-projects completed or being undertaken across the region ranging from artificial islands in Dubai to relatively smaller, but still immense, construction initiatives that have served as the poster children for the development of the GCC economies; a disparate, but nonetheless pointed effort towards achieving a better future scenario for the region.

Statistics and scenarios aside, however, it is clear that the fast-growing cities of the GCC will continue to draw the world's attention for the foreseeable future for reasons little to do with energy security; and for a citystate such as Singapore, determined to re-engineer its economic space, it presents new opportunities for Singapore companies to leverage on its track record in city-scale infrastructure implementation. The countries (Bahrain, UAE and Saudi Arabia) chosen for this paper have, in fact, shown a keen prior and current interest towards supporting a Singaporean business presence within their borders; Singapore's positive reputation and service offerings, it seems, help to ensure a strong positioning in GCC government and business circles, further aided by the "looking east" strategy adopted by GCC countries, post-911.

Singapore's Foray in the Gulf Region: The Singapore government's role as a facilitator and partner is evident from the creation of familiar and friendly Singapore-havens (via industrial parks in neighboring countries) and the restructuring of tax policies. The state also embarked on fostering trusted regional networks identical to those within its domestic market, whereby interlocking interests and a perceived commonality of values were to crystallize a system of cooperative competition. Implicit in this stratagem was the government's intent to draw on its state enterprise network or, in local parlance, Singapore Inc., and extend this network to facilitate business ventures in the region. This strategy to remain economically competitive in the global economy has been characterized by the building of platforms for national growth through the management of strategic alliances and 'collaborations' with private or semi-private enterprises on national economic projects. Theoretically, the 'vested interests' within the interlinked collaborative system were to serve to expedite processes, garner exclusive incentives, and negate inept bureaucracy; like parts in an intricate and complex machine (Yeoh et al, 2004).

This strategy itself is a synergy of state intervention policies. Political leaders, in the initial phase, negotiate the projects' institutional framework that typically involves the garnering of special investment conditions in the host locations. They also secure endorsements from host-country governments to provide political patronage and protection to the projects, which are critical for attracting potential investors. Following which, government-led consortia, typically comprising of Singapore government agencies and governmentlinked companies (GLCs), take on the role of primary investors in the Singapore-styled developments; justified by the perceived reluctance of firms in the private sector to take on investments of such gargantuan scale, and given the considerable time lag before any realization of investment would materialize. Moreover, the high risks involved in venturing into a relatively undeveloped and unfamiliar locale renders such projects inherently unattractive to private enterprises, due to the uncertain political climate and investors' interests. 
The Singapore government takes on the role of a 'business architect' and 'knowledge arbitrageur', identifies business opportunities, and brings together the private sector and commercial segments of the public sector in Singapore, as well as foreign companies with specific competencies, to undertake these large-scale investment projects. The presence of government agencies and government-linked companies adds weight to this internationalization stratagem.

There is a strong demand for Singaporean presence in the Gulf region, and Singapore's service offerings have a strong positioning. The Singapore brand is highly regarded, seen as a standard of quality in Arab government and business circles. They are keen to learn from Singapore's track record in city-scale infrastructure implementation. With most Middle East economies dominated by government spending, especially through state-backed GLCs, it is easy for Singapore to fully capitalise on the city-state's positive reputation. This is further aided by the "looking east" strategy adopted by GCC countries, post-9/11.

Singapore companies entered the $1^{\text {st }}$ phase of the GCC boom with architects, developers and master planners having successfully marketed the Singapore brand and excellence in the region (International Enterprise Singapore, 2007/2008). Broadly classified, Singapore companies that have made the internationalizing journey to the GCC countries fall into several classifications, with Singapore GLCs such as CapitaLand, Jurong International, Keppel Land/Keppel O\&M, SembCorp Industries and ST Engineering, amongst others, leading the way into this relatively new frontier of investment and internationalization, but with non-GLCs in consultancy services (e.g. Banyan Tree, DP Architects and RSP Architects), lifestyle and entertainment services (e.g. Cathay Cineplex), food and beverage operations (e.g. BreadTalk, Corona and Fish \& Co) and retail-franchise arrangements (e.g. Charles \& Keith, Osim and Royal Sporting House) following close behind, relying for the most part on their own business acumen and strategies, but taking advantage of support from both Singapore governmental entities, such as International Enterprise Singapore, and business groups, such as the Singapore Business Federation (SBF), which have also taken a keen interest in the internationalization efforts.

Markedly different, however, is the precise strategy adopted by the city-state in the GCC countries; while, due to a current focus on expansion and construction, the industrial-park or business-park model is untenable. Absent, too, is the highly interventionist and state-led strategy seen in the previous Regionalization 21 program. Singapore GLCs are still prevalent, but appear to have been given a freer hand, more in line with the ' $\mathrm{C}$ ' then the 'GL'; this corporate-represented internationalization, it seems, is the 'new way' forward for the Singapore government - at least in the Middle East - and represents a distinct departure from their previous stratagem. The next section presents selected case studies of Singapore's GLCs in Bahrain, the United Arab Emirates and Saudi Arabia, their experiences thereof, and the insights that may be gleaned from their gambits.

\section{Case Studies}

Company A: Property Development (Industrial): As one of Singapore's GLCs extending forays into the Middle East, Company A focuses on industrial development projects, rather than hospitality, retail or lifestyle developments. While initially purely a consultancy firm, the company has recently expanded into the actual planning of industrial townships, and is currently engaged in an iconic industrial development in Abu Dhabi. It has also since established offices in other emirates in the UAE, Qatar and recently, Saudi Arabia.

Company A is, in fact, a relatively recent entity, having been incorporated in 2001, but being a GLC, inherited much of its staff, contacts, contracts, and operational procedures from its parent agencies and companies. Its current contract in Abu Dhabi, indeed, appears to have been one of these inherited contracts; its parent bodies having initially been invited to review the abovementioned development before its incorporation. As such, the company shares many of the aspects of the GLCs of its type, including the mechanism by which it entered the Middle East - through invitation - and the issues which it has encountered thus far, including, at the current time, the presence of many internationally renowned players in the property development sector having arrived and established themselves beforehand. The company has, however, developed a positive reputation for itself in the years since its conception; partially owing to the large degree of autonomy granted to its regional offices, which results in a greater capacity for adaptation to local socio-political forces, and eliminates the time delay that a greater reliance on the home office in Singapore would spawn. And, indeed, the company appears to have been rather more proactive in its internationalization approach than most; 
while, like many other GLCs, its chosen mode of entry is through joint ventures and partnerships with politically powerful partner firms (often local GLCs themselves), Company A appears to have been the inviter as often as it has been, so to speak, the invitee. This is, we feel, a positive contributor towards the company's nascent but growing reputation in the Middle East, and appears to have been a key factor in their relatively rapid expansion across the region. Another contributing factor, perhaps, is the company's stated focus on teamwork and integrity; a focus that not only echoes Singapore's purported selling points, but resounds with their highly social and trust-oriented Arabic partners.

Yet, these same 'selling points' contain an issue endemic to most GLCs expanding into the region; the expectation, from both local partners as well as the home office, of the company exporting Singapore's qualities of efficiency and reliability. From the home office, this translates into pressure on the company to achieve goals not immediate to the success of their projects, or indeed to their operations in general; from local partners, this creates the perennial risk of the occurrence of an expectation gap resulting from the impact of socio-political factors. Thus far, however, such disconnect in goals and communication does not seem imminent; perhaps, indeed, precisely because of the company's relatively recent 'conception'. Company A, in fact, appears to be one of the more positive role models among Singapore's GLCs in the Middle East thus far; a testament, perhaps, to a more decentralized approach to Singapore internationalization, and one with less political baggage.

Company B: Property Consultancy (Township Planning \& Consultancy): Company B, like many of its GLC peers, boasts an impressive local portfolio; having been a key player in Singapore township planning for several decades and effectively having housed a significant percentage of the population. Similarly, said company has been often on the frontlines of Singapore's government-led internationalization initiatives, and currently has operations of varying scales across over 24 different countries.

Company B possesses multiple-operation arms across the property \& development industry, and is more fully engaged in the Middle East (most notably Abu Dhabi), with a number of branches and subsidiaries engaged in township planning, consultancy, and more recently, even management services, with a contract in Dubai this year; seemingly quite undaunted by the prospect of tackling this yet relatively new market on multiple fronts. This is ostensibly in line with the company's brand image of integrated and customized one-stop solutions; but while the advantage of bringing the company's full competencies and brand value to bear at once is clear - that the company will be competing in full strength and with the ability for distinct operations arms to support each other - it is not a strategy without risk, to say the least.

Reflecting the distribution of Company B's current commitments in the region, Abu Dhabi houses a satellite office with a large degree of autonomy, but only subordinates project offices in Qatar and Dubai, with limited decision-making authority. While Abu Dhabi is arguably a suitable operational base for the region, it is a fact that, given the sometimes substantial cultural differences even between such neighbour states, there exists a possible risk of transfer of non-compatible practices and business habits between these offices, one possibly exacerbated by the staff complement being Singaporean in the majority.

In terms of local relations, Company B displays a similar emphasis with Company A on good relations with local partners, replete with building relationships on a more personal nature between key individuals in Company B and its partner firms; but also purports to take a more cautious approach with regards to information and technology exchange, having apparently exacted payment for additional information exchange in the past; a measure not without precedent, but one with the potential to cause bumps in the road of relationship-building, and thus providing both merit and demerit. And both said potential merit and demerit quickly multiply in import given Company B's other similarity to Company A; their aggressive engagement of local firms and proactive seeking of projects in the region. Perhaps, like Company A, Company $\mathrm{B}$ is gambling on building a positive brand reputation. If this is so, then results are probably mixed; to date, the company has had its share of setbacks and complications in the Middle East, though none catastrophic or unresolvable - as yet.

'As yet', we say, because the company's entire strategy speaks of all-in engagement; and all-in engagement is never without risks. This is especially so for Company B, given that the company's main experience in 
Singapore is with cheap, efficient housing - completely different from the trend and demand in the Gulf states - and does indeed have limited resources to tackle large-scale developments with. The question, perhaps, is one of sustainability; if so, only time will tell if Company B's rate of expansion will trip itself up later down the road. The company's current record seems overall positive (possibly due to, like A, a relative lack of political baggage), but at the rate at which Company $B$ is entering new projects across various sub-industries requiring differing skill sets, the risk of over-differentiation and over commitment is not zero, by far.

Company C: Property Development (Residential): Company C represents the property development arm of a larger government-linked group. Possessing a long history as one of Asia's major property developers, Company C has (unlike some of its GLC peers) both deep pockets and a significant amount of experience with developments on a larger scale than Singapore's domestic market normally provides opportunity for.

Oddly enough, among other countries in the Middle East, the company chose to focus its attention the development of a large-scale residential property in Saudi Arabia, which the company terms a 'mid-level' entry, and no further projects appear to be forthcoming at this time. The company has undertaken this commitment through joint ventures with a prominent and well-connected local firm, with the joint venture shouldering the entire responsibility for the said project; even though that does not significantly lower the risk for the parent company. Perhaps this explains the company's relatively laconic approach to expansion in the Middle East - seemingly content to focus on this one project instead of seeking other concurrent projects, and having a relative 'mid-scale' entry to lower risk exposure. In the same fashion, Company C's sibling companies have chosen specialization rather than diversification of operations in their native industries such as the Maritime industry. Caution, it seems, is endemic to Company $\mathrm{C}$ and its associates, insofar as their Middle East internationalization plans go.

And given recent events in the region, this degree of caution may have been somewhat prescient; as it was, the financial debt crisis, as well as a sudden change in property laws regarding land ownership of such projects, was a contributing factor to the delay of the abovementioned project, on which construction has, to this day, yet to begin. The project itself, at least, appears to be now back on track, with bidding for construction companies having been offered recently; but further complications now potentially await the development, from sterner economic competition arising from completed and upcoming developments in the vicinity, to possible social complications arising from what appears to be a disconnect between the development's stated target market of both expatriates and locals, and the actual needs and wants of potential local customers. Locals have raised several reservations - about sharing lodgings with non-Muslim expatriates, the affordability of the luxury apartments themselves, and a general dislike for high-rise lodgings in general. What this seems to signal, then, is a possible general disconnect with the local socio-political environment - which seems somewhat inexplicable given the local partner component of the joint venture company through which Company $\mathrm{C}$ is undertaking this project - or at the very least limited sharing of information with the local partner, despite evidence as to frequent contact and discussion with said partner. Certainly the company does not seem to think such a disconnect exists, claiming high interest in the first phase of the project; only time will tell which will prove to be the case.

Insights, Issues \& Challenges: Our research on the internationalization of Singapore companies into the GCC reveals a somewhat disturbing, but not altogether unexpected, reliance on local (GCC) partners and equally Singaporean third-party organizations such as IE Singapore to shield firms, government-linked or otherwise, from the region's reportedly rocky socio-political forces. The 'partnerships' with host governments (that were the chosen vehicle for Singapore's regionalization initiatives) are a strategy with obvious limitations. Some are immediately apparent, such as the possibility of conflicting goals causing friction between partners, and threatening to derail the project itself, and some initially less so, until some years further on, when Singaporean companies find themselves with limited relevance due to 'local partners' learning from their processes and expertise. The former, in the wake of the global financial crisis, have already emerged, with the primarily business concerns of local partners finding areas of disconnect with their Singapore counterparts, amidst financial aftershocks. At the point of writing, it is unknown, and somewhat doubtful, whether many of the Singapore companies will be able to step up to the plate for the challenge of 'doing business in the Gulf region' without a guiding hand, given the abovementioned narrow focus and overly cautious entry shown by some of 
the case-study companies. Most Singapore companies, it seems, have yet to embrace fully a true entrepreneurial mindset in their internationalization efforts.

Conversant to the above, the transfer of core competencies by these companies to their operations in the Gulf region appear to have been, by and large, been performed under the aegis of the same local partnerships, with rather mixed results. It is plausible that not enough competencies may have been imported into their GCC operations; certainly not enough to have conclusive, or even inferential, proof as to how effective the said competencies may or may not have been.

Intuitively, and interestingly, we find that firms with a more international focus, in this case, Companies $\mathrm{A}$ and $\mathrm{C}$, have had fewer issues with the new socio-political environments of the Gulf region - presumably due to said more international focus, as opposed to a preoccupation with domestic issues, creating a greater flexibility in operations. This often translates to an equivalent willingness to adapt. Such an international focus is also generally less conducive to the identification of particular business concepts and qualities as 'core competencies' - which, by and large, we find unhelpful, and possibly even hindering, operations in the Gulf region Thus, the theorized necessity for 'new viewpoints' - for companies to leave behind preconceptions and realize the greater need for companies to enact change in response to challenges in new business environments, to build new wings to their business with expertise, but not expectations. It is interesting, to say the least, that a relatively new entity among Singapore GLCs (e.g. Company A), should seem to find less trouble in taking a pro-active, international, and adaptive approach to business in the GCC countries.

\section{Conclusion}

Our previous research into Singapore's regionalization programs provides telling evidence towards the critical importance of the socio-political dimension towards the location and eventual performance of international investment, hinted at in the works of Dunning and other scholars, but not fully explored in the context of the influence of these socio-political nuances that radiate from, and on the business derived thereof, within the borders of the host environments. As well, this relatively small (albeit rich) investment region abounds with a host of variances - minor and major - across socio-political environments; most especially in the UAE, where even intra-country socio-political environments may vary so deeply, as to provide an entirely different set of opportunities and challenges to firms entering these respective areas of the country.

In perspective, Singapore's optimism over the initial wave of internationalization into the GCC was based not just on riding the general wave of enthusiasm into the region, but also encouraged by a series of perceived advantages at the onset, including a generally high opinion of Singapore and Singapore companies in the GCC. As well, the links between many of the initial local partners with local governments (and/or prominent local governmental individuals) were thought to provide added security against political risks. In reality, however, the vagaries of political patronage (and personal) ties, rather than transparent contracts, has proved challenging for Singapore companies, government-linked or not. Furthermore, reliance on local partners to shield from socio-political forces has had rather mixed results so far, even for government-linked companies; due, perhaps, to the sometimes abrupt nature of communication with local partners, and a rather lower degree of information exchange than might have been originally posited.

Our research further points to negative undercurrents over Singapore-styled management practices, and these have translated into perception differences, protracted conflicts and project delays - many of which were initially negligible, but which were exacerbated and rendered no longer ignorable by the financial crisis. Official commitment to the projects remains, in the willingness of the Singapore's government-linked companies to cut alternative strategies to restructure, and reposition, projects that have stalled or otherwise run into complications, so as to reflect a better alignment of interests, along with dealing with immediate issues. Notably, it seems that companies involved in smaller-scale projects face far fewer of these issues; possibly pointing again to Singapore companies being less than quite prepared to handle the relatively larger scale, in various senses of the word, business in the GCC.

Even as a standard internationalization stratagem seems apparent and even encouraged, our research unveils a realization that a preserved economic strategy may not always be the most fitting solution in a complex and 
enigmatic region, and the exporting of the Singapore system, often thought superior due to its much publicized success, cannot be achieved without expecting any form of backlash and subjugation from the local environment.

\section{References}

Abouchakra, R., Chadi, M., Mazen, N. \& Richard, S. (2008). Economic Diversification: The Road to Sustainable Development, Abu Dhabi: Booz, Allen \& Hamilton.

Blomqvist, H. C. (2001). State and development policy: the case of Singapore. Asian Profile, 29, (ERN APS 7(2), 01162002).

Dunning, J. H. (1988). Explaining International Production, London and Boston: Unwin Hyman.

Dunning, J. H. (1995). Re-appraising the eclectic paradigm in an age of alliance capitalism. Journal of International Business Studies, 26(3), 461-491.

Dunning, J. H. (1997). Alliance Capitalism and Global Business, London and New York: Routledge.

Dunning, J. H. (1998). Location and the multinational enterprise: a neglected factor? Journal of International Business Studies, 29(1), 45-66.

Dunning, J. H. (2001). The eclectic paradigm of international production: past, present, and future. International Journal of the Economics of Business, 8(2), 173-190.

Dunning, J. H. \& Narula, R. (1996). Foreign Direct Investment and Governments: Catalysts for Economic Restructuring, Routledge: London and New York.

Dunning, J. H. \& Narula, R. (2000). Industrial development, globalization, and multinational enterprises: new realities for developing countries. Oxford Development Studies, 28(2), 141.

How, W. \& Yeoh, C. (2007). The internationalization of Singapore's state-enterprise networks in the context of Asia's transborder industrialization: further evidence from Indonesia, Vietnam and China. Journal of Asian Business, 23(1), 1-25.

Huff, W. (1995). The development state, Singapore, and Singapore's economic development since 1960. World Development, 23(8), 1421-1438.

International Enterprise Singapore (2007/2008). Beyond Singapore: Opportunities and Challenges for Singapore Companies Going Overseas (Middle East), various issues.

Jovanovic, M. N. (2003). Spatial location of firms and industries: an overview of theory. Economica Internazionale, 56(1), 23-82.

Lundan, S. (2003). Institutions, exclusivity and foreign investment', in H. Peter Gray (ed.), Extending the Eclectic Paradigm in International Business: Essays in Honor of John Dunning (93-105). Cheltenham: Edward Elgar.

Mahizhnan, A. (1994). Developing Singapore's external economy, in Southeast Asian Affairs 1994, Institute of Southeast Asian Studies: Singapore, 285-301.

Markusen, A. (1996). Sticky places in slippery space: A typology of industrial districts. Economic Geography, 72(3), 293-313.

Okposin, S. B. (1999). The Extent of Singapore's Investment Abroad, Ashgate: Aldershot.

Peck, F. W. (1996). Regional development and the production of space: the role of infrastructure in the attraction of new inward investment. Environment and Planning, 28, 327-329.

Perry, M. (1995). New corporate structures, regional offices and Singapore's new economic directions. Singapore Journal of Tropical Geography, 16(2), 181-196.

Porter, M. E. (1994). The role of location in competition. Journal of Economics of Business, 1(1), 35-39.

Porter, M. E. (1996). Competitive advantage, agglomeration economies and regional policy. International Regional Science Review, 19(1\& 2), 85-94.

Porter, M. E. (1998). Clusters and the new economies of competition. Harvard Business Review, Nov-Dec, 7790.

Porter, M. (2000). Location, competition and economic development: local clusters in a global economy. Economic Development Quarterly, 14, 15-34.

Regnier, P. (1993). Spreading Singapore's wings worldwide: a review of traditional investment strategies. The Pacific Review, 6, 305-312.

Singapore Economic Development Board (1993). Regionalization Forum (Conference Proceedings), May 2123. 
Singapore Economic Development Board (1995a). Singapore Unlimited.

Singapore Economic Development Board (1995b). Regionalization 2000.

Singapore Ministry of Finance (1993). Final Report of the Committee to Promote Enterprise Overseas.

Stopford, J. (1999). Implications for national governments, in J.H. Dunning (Ed.), Governments, Globalization, and International Business (457-480). New York: Oxford University Press Inc.

Tan, C. H. (1995). Venturing Overseas: Singapore's External Wing, McGraw-Hill: Singapore.

World Economic Forum (2007). Gulf State Scenarios: GCC Countries and the World: Scenarios to 2025.

Yeoh, C., Cai, J. L. \& Koh, C. S. (2004). Singapore's regionalization blueprint: a case of strategic management, state enterprise network and selective intervention. Journal of Transnational Management Development, 9(4), 13-36.

Yeoh, C., How, W. \& Sim, V. (2006). Re-engineering economic space: the Case of Singapore's transborder industrialization 'gambits' in Asia, Journal of Asia Business Studies, 1(1), 34-45.

Zutshi, R. \& Gibbons, P. (1998). The internationalization process of Singapore government-linked companies: a contextual view. Asia-Pacific Journal of Management, 15(2), 219-240. 